Open Access

\title{
Retraction Note: TREEFINDER: a powerful graphical analysis environment for molecular phylogenetics
}

Gangolf Jobb ${ }^{1 *}$, Arndt von Haeseler ${ }^{2,3}$ and Korbinian Strimmer ${ }^{1}$

\section{Retraction}

The editors of BMC Evolutionary Biology retract this article [1] due to the decision by the corresponding author, Gangolf Jobb, to change the license to the software described in the article. The software is no longer available to all scientists wishing to use it in certain territories. This breaches the journal's editorial policy on software availability [2] which has been in effect since the time of publication. The other authors of the article, Arndt von Haeseler and Korbinian Strimmer, have no control over the licensing of the software and support the retraction of this article.

\section{Author details}

${ }^{1}$ Department of Statistics, University of Munich, Ludwigstr. 33, D-80539

Munich, Germany. ${ }^{2}$ Department of Computer Science, University of

Düsseldorf, Universitätsstr. 1, D-40225 Düsseldorf, Germany. ${ }^{3}$ John von

Neumann Institute for Computing, Forschungszentrum Jülich, D-52425 Jülich,

Germany.

Received: 19 October 2015 Accepted: 20 October 2015

Published online: 05 November 2015

\section{References}

1. Jobb G, von Haeseler A, Strimmer K. TREEFINDER: a powerful graphical analysis environment for molecular phylogenetics. BMC Evol Biol. 2004;4:18.

2. BMC Evolutionary Biology's Instructions for Authors of Software Articles: http://www.biomedcentral.com/bmcevolbiol/authors/instructions/software. Accessed 15 October 2015.

\footnotetext{
*Correspondence: gangolf@treefinder.de

The online version of the original article can be found under doi:10.1186/1471-2148-4-18.

'Department of Statistics, University of Munich, Ludwigstr. 33, D-80539

Munich, Germany
}

Submit your next manuscript to BioMed Central and take full advantage of:

- Convenient online submission

- Thorough peer review

- No space constraints or color figure charges

- Immediate publication on acceptance

- Inclusion in PubMed, CAS, Scopus and Google Scholar

- Research which is freely available for redistribution 